\title{
The making and legitimacy of the Ethiopian constitution: towards bridging the gap between constitutional design and constitutional practice
}

\author{
Tsegaye Regassa \\ Institute of Federalism and Legal Studies, Ethiopian Civil Service College, \\ Addis Ababa, Ethiopia
}

\begin{abstract}
This article describes the making of the 1995 constitution of the Federal Democratic Republic of Ethiopia (FDRE) and analyzes its implications for legitimacy. It contends that legitimacy of the constitution, which fosters fidelity to it, can -as one among other factors- help bridge the gap between constitutional design and constitutional practice. By making a process-content-context analysis of the constitution, it argues that the Ethiopian constitution which had a weak original legitimacy, can earn a derivative legitimacy through aggressive implementation. Aggressive implementation, it is maintained, demands fidelity to the constitution. Fidelity and other components of a redemptive constitutional practice (such as creative constitutional interpretation, constitutionally informed legislation, positive constitutional amendment, and constitutionally responsible voting) help deal with the perennial question of how to bridge the gap between constitutional design and constitutional practice in Ethiopia and beyond.

Key words: Ethiopia, making of constitutions, constitutional legitimacy, fidelity to constitutions, constitutional redemption
\end{abstract}

\section{Introduction}

How do we bridge the gap between constitutional design and constitutional practice? Asked in a more conventional tone familiar among legal scholars, this question can be reframed as follows: how do we reconcile the disparity between the law and the practice? A related question is also the question of how to design a constitution that is legitimate so that the gap between law and practice is narrowed, if not entirely filled. These questions all point to the issues of constitutionalism. Needless to say, in the context of Africa in general and the Horn in particular, the question of how to bridge the gap between constitutional law and constitutional practice is very important. The question is evocative of concerns with constitutionalism.

Constitutionalism and constitution writing is gaining salience in recent years. This salience dispelled the 'constitution-scepticism' that pervaded the era preceding the 
I990s. After the collapse of the Soviet Union and the authoritarian regimes in former 'Eastern Bloc' countries, interest in constitutionalism became especially acute in those countries. This also became a pattern in other countries who sought constitutional renovation elsewhere. See Ackerman (1992) for a description of how, with the liberal triumph, constitutionalism became once again prominent. For the salience of constitutionalism and interest in it in the West itself, see for instance, Fleming (2006), Tushnet (1999) or Sunstein (1992).

Interest in writing or rewriting constitutions is clearly on the rise. This is the case in post-communist East and Central Europe. It is also the case in Africa. In Africa, Namibia, South Africa, Uganda, Ethiopia, Eritrea, Somaliland are all engaged in constitutionmaking since I99I. This is even truer in post-conflict societies, in societies that emerged out of protracted conflicts, where the tragedy and subsequent trauma of violent conflicts still reverberate. Afghanistan and Iraq come readily to the mind. But there are others in Africa such as Eritrea, Somalia, Rwanda, Ethiopia, and others. Some commentators, such as John Markakis - who links constitutions to struggles for power among contending political actors, beginning with the bourgeoisie and the monarchs of 18 th century Europe - observe that "constitution-making follows the end of foreign and civil wars." (Markakis 2007: 49). In such societies, constitutions come primarily (and more immediately) as instruments of truce, as a peace document, or a pact between warring factions. As such, they stand in contrast to contracts among peoples and between them and their governments. When constitutions are viewed only as pacts, they tend to be an agreement between conflicting factions rather than as covenants among the peoples that these factions say they represent. They mark deals between self-proclaimed representatives of their supposed constituencies. In such circumstances, they serve as an inter-elite "treaty" rather than as an inter-popular covenant that binds a polity together. They come as a tool of conflict resolution, a tool of peace making/peace keeping for the present and of peace building for the future. They serve as an instrument of conflict transformation. As instruments of conflict resolution, they mark the end of an overt and violent conflict. As tools of conflict transformation, they mark the beginning of new relations on the basis of mutual understanding of what led to the conflict in the first place and in such a way that it can guarantee the protection of the interests that were at stake. The making and legitimacy of constitutions is of pivotal significance in such societies. At least, it is as important as it is in societies that are being constituted anew as fresh polities. Of course even in postconflict societies, to the extent that they view the post-conflict moment as a moment of rapture and a radical break with the past, because the constitutions mark the remaking of polities, the making and legitimacy of constitutions continue to be as pivotal as they are anywhere else. This is no different in Africa, where recent years witnessed the rewriting of post-independence constitutions in such a way that they can redeem an authoritarian past or they can heal the conflicts that emerged as a consequence of that authoritarian past. Rwanda is a good example of this. But the recent constitutional 'negotiations' in Kenya, and the interest in amending the constitution in Zimbabwe can also be mentioned as part of the quest for 'redemption' through a constitution. 
Writing or rewriting of constitutions is not a rare phenomenon in Africa. What is rare is implementation, at least to the satisfaction of most of their peoples. The quest for more constitutional practice is what is often called for, more than the quest for a new constitutional writing. An-Naim (2003: I4) points to this problem of the rift between law and practice in Africa when he pointed out the fact that "the vast majority of first constitutions were actually either suspended or radically altered by military usurpers or single party states within a few years of independence." He attributes this problem to the salience of constitutions without constitutionalism in general, but he also specifically points to the historical fact that the constitutions and the concept of the nation state that they espoused are more externally imposed (be it "voluntarily received", as it was the case in Ethiopia, or otherwise) than evolving "out of the lived experiences and cultural values of African societies" thereby stunting indigenous growth. So it is a truism that implementation rests not on the beauty of the constitutions written but on the commitment to give effect to the letter and spirit of the constitutions.

In the context of Ethiopia, the issue of the making and legitimacy of constitutions is no less important. Ethiopia has adopted a new constitution in 1995; in fact, the constitution was adopted in the constituent assembly on the 8th of December 1994. It came into "full force and effect" as of the 2ist of August 1995. (See the Proclamations [issued] to Pronounce the Coming into Effect of the Constitution of the Federal Democratic Republic of Ethiopia, Proclamation No. I/ I995, Federal Negarit Gazeta, Year I, No.I.). Consequently, I refer to the FDRE Constitution as the 1995 constitution throughout this piece. Jon Abbink (I997: $\mathrm{I} 66$ ) makes an interesting observation that " $[\mathrm{t}]$ he Constitution was published on 12 December 1996, with the imprint '21 August 1995' (the date of inauguration of the FDRE)" although "the reason for the delay is not known." Subsequently, Ethiopia has been trekking on the way to implementing the constitution, but the legitimacy of the constitution is not without controversies that surround it. There were times when it was said that the constitution is nothing more than the program of the party in power. (This is a sentiment shared by many "opposition" politicians. On the wake of the 2005 election, for example, a senior but retired member of the Tigray People's Liberation Front (TPLF) said, in an interview with the Voice of America (Amharic Service), that the constitution is nothing more than TPLF Program, TPLF being a core, founding, and still dominant member of the coalition of ethno-nationalist political organizations broadly known as the Ethiopian Peoples' Revolutionary Democratic Front (EPRDF)). It is important to note that the core and oldest member of the EPRDF is TPLF. In the late 8os and early 9os, the TPLF formed a guerrilla coalition with Ethiopian Peoples' Democratic Movement (EPDM) - which was later changed into the Amhara National Democratic Movement (ANDM) - and the Oromo People's Democratic Organization (OPDO). Owing to its long experience in the armed struggle, the TPLF has remained the strongest and dominant core of the EPRDF to date. Hence, the association of the regime and the constitution with TPLF. In 2005, a competitive election was held in which the Coalition for Unity and Democracy (CUD) came out as one of the strongest opposition political parties in Ethiopia. Notable among these parties were also the Union of Ethiopian Democratic Forces (UEDF) and the Oromo Federalist 
Democratic Movement (OFDM), although the latter won a relatively smaller number of the parliamentary seats at the national level. The latter two parties are reported to have won a sizable number of seats in Oromia, one of the Regional states of the federation: about 170 out of a total of 537 . There were also political parties who sought, if elected, to amend a number of provisions of the constitution. For example, the Coalition for Unity and Democracy (CUD) has had a manifesto in which it maintained that there are provisions of the constitution it seeks to change should it assume power. The provisions oftreferred to were article 39(I) (on the right of ethnic groups to secession) and article 40 (3) (on the right to state ownership of land). The fact that these sentiments and interests (one identifying the constitution with the TPLF program and the other calling for the amendment of the core aspects of the constitution) - while possibly being seen as positive engagements that help enhance the dynamism of the constitution thereby changing it into a 'living constitution' - are both a manifestation of a type of discontent with regard to at least some aspects of the content of the constitution. The discontent, I argue, is a mirror of the lack of original legitimacy that the constitution suffers from. These disaffected sentiments were only symptomatic of a larger question, the question of legitimacy of the constitution. These questions unveiled the fact that the constitution's legitimacy is not an entirely decontested 'truth'. The question of legitimacy gains importance in Ethiopia also because, as in all other federations, the existence of a legitimate, supreme, and rigid constitution is a vital component of the federal experiment.

This paper is primarily about the making and legitimacy of constitutions. It is about the relation that making and legitimacy have to constitutional implementation. More specifically, it is about the link between constitutional design ${ }^{1}$ (making) and constitutional practice (implementation). The assumption is that the right approach in the making helps foster legitimacy. A better or 'optimal' degree of legitimacy fosters better enforcement. The making and legitimacy better foster fidelity to the constitution. Fidelity makes the constitution not only a "basic law, or a higher law," but "our law" (see Balkin 2007). This in turn helps us engage in the enterprise that Jack Balkin calls redemptive constitutionalism (or redemptive constitutional interpretation.) (see Balkin 2007; 2008: 5, 70).

In this paper, I seek to address myself to the following set of questions: What does constitutional design (the making of constitutions) involve? What does it take to design a legitimate constitution? What are the steps involved? What are the factors that help ensure better constitutional implementation (the practice)? How does the making impinge on the process of redemptive constitutionalism? Of course all these questions are addressed by drawing from the recent experience of Ethiopia. Thus I will discuss, albeit in an outline format, the making and legitimacy of the Ethiopian constitution.

I will address these questions in the following order. Following this introduction, in section two, I will discuss the issue of what constitutional design involves. In the third might be used to refer to the content of the constitution whereas the latter might be used to refer to the process of constitution-making. In this article, both terms are used interchangeably only to refer to the process of constitution-making. For the content, the term "structure" or just "content" is used. 
section, I will deal with the issue of what factors foster good constitutional practice. Thus an attempt will be made to identify the factors that contribute to the effective implementation of constitutions. In section four, I discuss descriptively, the making of the Ethiopian constitution. In this section, I will also explore the issue of legitimacy of the Ethiopian constitution. In section five, I discuss the issue related to fidelity to the constitution to see whether redemptive constitutional practice (and interpretation) can help better enforce not only the rules of, but also the values and principles behind, the constitution. In section six, an attempt will be made to draw some conclusions.

\section{Constitutional Design: What does it involve?}

Designing a constitution is "more than the arid preparation of a constitutional document." (see Elazar 1985: 232-248; I994: II-I3). Depending on the "character" of the polity for which it is designed, and the model of constitution we adopt for the purpose, the process of constitutional design might take different forms. Often the process involves the structuring or restructuring of the political landscape of a nation. Often it happens at a rapturous moment, a "constitutional moment" (see Weiller 1999: 3; Sajo 1999). In old polities that have had a chequered past, a new written constitution serves as an instrument that synthesizes both change and continuity, with an accent on the change. This is partly because the continuity is maintained unconsciously to, among others, preserve the core identity, alias the 'national character', of the country, to reaffirm its territorial expanse, to affirm the traditional sources of legitimacy, etc. In a polity that has a history that current political actors seek to contradict (perhaps because they have supposedly suffered from it), constitutional drafting marks a break with the past. This is often the case in countries where history, owing to the multiplicity of historical narratives, is contested, and where revisionist historiography becomes dominant among the makers - as a consequence of which the past is doomed to be thrown away. One can see a typical example of this in the salience of ethno-nationalist histories in Ethiopian and Eritrean nationalist histories in the course of the making of the Ethiopian transition to the 1995 constitution and Eritrean independence respectively.

With regard to 'national character', Daniel Elazar (1994) identifies three types of polities, namely I) those formed through conquest; 2) those formed through evolution; and 3) those formed through design, i.e., 'reflection and choice'. Elazar identifies these three types of polities following the tack of Alexander Hamilton (I999: I) in the Federalist Papers (No.I). For Elazar's reference to The Federalist No.I, see Elazar (2006: 2). The first category of polities is exemplified by authoritarian and imperial polities that are wielded together by force. In such polities, power is concentrated and structured hierarchically at the top of the pyramid of which is the (executive) leader. Power is centralized. In such systems, constitutions are often viewed as a grant given to the people by the rulers. Note however that even in polities where constitutions are more like a contract than a grant, the people "give" themselves a constitution. Consider the example of India and Ireland in this regard. The preamble of the Irish Constitution of I937 reads as follows: "We the people of Eire, do hereby adopt, enact and give to ourselves this constitution." The Indian 
Constitution, apparently following the tack of the Irish example, reads: "We the people of India, ... in our Constituent Assembly, ... do hereby adopt, enact, and give to ourselves this constitution.". Note the idea of the people being the self-giving sovereign here. Consequently, the process of constitution making is relatively easier in this system than in the other two categories of polities. The legitimacy of the exercise of governmental power emanates from the use of force which, under a constitution, is only given a legal basis. Legitimacy of governmental power rests outside of the text of the constitution, often in the efficacy in the mobilization and utilization of military skills. Ugo Mattei refers to the importance of the military effectiveness (in the war for independence) of the Eritrean People's Liberation Front (EPLF) as the source of legitimacy, as distinct from a democratic process typified by election or a constitution (which has never been signed into force anyway). See Mattei (1998: 12) where he says: "In Eritrea elections have been promised but never actually carried on. They have been felt useless. Legitimacy of the leadership is grounded elsewhere, typically in the war. Generally speaking traditional legitimacy and skilful use of force are still the leading legitimating factors in Africa." When such is the case, the country becomes an example of a system with a constitution but without constitutionalism. See Jain (1994: 3-4) which is instructive on the distinction between constitutions and constitutionalism. Legitimacy of the constitution rests not on the consent of the people but rather on the political will of the rulers or the extent to which the constitutional texts validate the politico-military sources of legitimacy in the country. The authority of the constitutions is compromised to that extent. At best, they will only have an asserted authority in such systems. Walter Murphy (I993: 7-I2) distinguishes between constitutions' asserted and exerted authority to refer to the authority they claim and the authority that they actually have respectively .

Returning to Elazar's categories of polities, the second category, the category of those formed through accident are organic polities that came to be what they are through a long gradual process of history. Constitutions are often made through imperceptible processes, mostly in conventions and incremental legislative enactments and habits. The legitimacy of the constitution and of the power of government rests in these invisible threads of tradition. The constitution-making process does not manifest any rapture. There is hardly a constitutional moment one can outrightly point to. The constitution invisibly evolves. Change happens silently. Nevertheless, the constitution (which is often unwritten) has an exerted authority that binds everyone principally because the vast majority of the people know the "constitution" by heart, or if they are late comers to the polity - like most immigrant communities in the West-, they acquiesce in it.

The third category is a category of polities formed by design, i.e., through popular reflection and choice. These are polities in which people, at least theoretically, come together to form the polity and determine the nature, function, and operation of their core governmental structures. In such polities, the making of constitutions involves a (constitutional) choice to be made among negotiating partners. The end result of the process is a written text which is often made fundamental (i.e., constitutive of the governmental institutions) and supreme. The written constitution that emerges out of this process 
serves, again at least theoretically, as a contract that binds not only the government to the people but people to people. Popular consent is a key factor in these kinds of polities both in the formulation and in the amendment of the constitution. Popular and democratic legitimacy is vital. Participation in the process ('coming to the table of covenant' can be used as a useful metaphor here) is important.

From among these kinds of polities, the ones in the third category are the ones in which the need for a rational legitimacy is predominant. In countries formed through the instrumentality of force, both the government and the constitution hardly need legitimacy apart from the force that created the polity in the first place. In organic polities, the making of the constitution is an unconscious activity. In polities founded by design, however, one needs to make sure that the process, the content, and the context are all optimal for the adoption of the text of the constitution. In other words, the makers should agree on both the process that led to the production of the constitutional text and the substance of its content. They also must agree on the socio-cultural and political context in which they anticipate the text to apply. Furthermore, they must agree on the values, causes, ideals, and aspirations they seek to promote by/and in the polity they are establishing. Finally, they must agree on the frame they lay down for the government that they seek to set up and run.

In order to achieve these, countries may choose one or more models of constitutions. Elazar (1985) identifies five major models of constitutions that are made use of the world over, namely: I) Constitution as frames of government and protectors of rights (such as those of Anglophone North America); 2) Constitution as code (such as those in Continental Europe and India); 3) Constitution as a revolutionary manifesto (such as those in former Soviet bloc countries and former Yugoslavia); 4) constitution as a political ideal (such as those in Latin American and African countries); and 5) Constitution as adaptation of ancient tradition (such as those in the UK, Israel, Iran). In fact, one might add Imperial Ethiopia in the fifth category.

The first two models continue to operate in their home countries, sometimes even having to be transplanted elsewhere. Ugo Mattei (r995a, b), a comparativist, observes that the American model - being the strongest of the first category of constitutions - is the most transplanted one. But it is also important to stress that the continental (constitution-as-code) model, especially the German one, is also borrowed and adopted in some East and Central European countries that emerged out of a communist past. It is further important to note that due, in large part, to the globalization trend (especially because of the intensified interconnection through electronic publications), there seems to be a convergence of frames of mind among intellectuals from countries of these varying models. Interest in the third model is subsiding or has subsided since the collapse of the Eastern Bloc countries as most of their constitutions have been replaced by either one of the first two models or by a creative amalgam of values extracted from both. The fourth model is tempered (and often overwhelmed by the drift to the first model) but seems to linger both in Latin America and Africa. It is not uncommon for one to hear people quip that the constitution is "an expression of aspirations" even in Ethiopia whose constitution 
tends to have adopted the first model. The fifth model continues to operate in the UK and Israel. The debate on whether Israel needs to adopt a written constitution and break with its traditionally unwritten but adaptive constitution continues unabated.

While the choice of the models depends on the objective the makers seek to achieve through the instrumentality of the constitution, the socio-political, cultural, and economic context they are in, and the ideals the makers seek the constitution to embody and immortalize, a country's constitution making process will vary depending on the model adopted. Thus if one chooses one of the first two models, then the process will involve a written constitutional text that serves either as a (general and brief) frame of government or a (detailed, often lengthy) manual of government. The more the choice tilts to the continental European model, the more the making process ends up becoming an exercise in technical legal professional elegance and finesse whereas the more it tilts toward the Anglophone American model, arguably the less preoccupation with technical legal professional elegance and finesse. One can also conjecture that the more professional, the less political the process becomes. The consequence of having to adopt a written constitutional text is to methodically and circumspectly determine the mode of preparing the draft, deliberating upon the draft, adopting the draft, and finally ratifying the draft so adopted. This in turn leads us to the steps involved in the designing of a written constitution.

Generally, scholars classify the steps in constitutional design into two: that of drafting and ratification. See, for example, Khan \& McNiven (1990: 148-I49), who say "The process of enacting a written constitution is composed of two separate activities: the formulation of the draft and its ratification by the people." More technically, the mechanics of constitution-making might involve three or four steps, namely that of: a) drafting; b) deliberation; c) adoption; and d) ratification. If constitutions have to serve as an instrument of founding a polity by design and if it has to generate a moral, sociological, and legal legitimacy that backs them in the long run, we need to note the following few points.

First, the drafting process - owing to the central significance the question of who should be the makers of the constitution as well as who is in and who is not in the polity - must be inclusive of the choices of the dominant actors. Drafting is often done by an executive body, or a legislative/deliberative body of a pre-constitutional moment. Or it might as well be by a body specially convened to do the drafting (Khan \& McNiven 1990: I49). The drafting body so constituted, as a technical body, must be accommodative of all the concerns and be able to capture the visions of all the stakeholders. As a technical work, it benefits from being non-political, although it is often difficult to be politically neutral at such a juncture in the history of a nation. The existence of pre-existing principles on which the "founders" agree upon will aid the drafters by serving as guiding sign posts to the progress of its work. Such was the case in South Africa where 34 principles were agreed upon by all the parties involved to be heeded to in the making of the final constitution under the 'certification' power of a Constitutional Court that pre-existed the constitution itself (see Johnston et al 1993: I-12, 54-66; Van Wyk et al 1995). Thus there 
needs to be an agreed upon terms of reference. Needless to say, drafting being primarily a technical work, technical professionalism predominates the process at this stage. At this stage, among other things, a search for a constitutional ingenuity tried and tested elsewhere is sought. Comparison, a search for an analogue, adaptation of foreign institutions, doctrines, and principles is undertaken. The adaptability and transplant-ability of the same is also explored.

Secondly, the deliberation stage must be broad-based (and thus inclusive), participatory, free, and a two-way traffic. Thus, all the relevant political actors and other stakeholders must be engaged. People must have the basic freedom to speak their mind (and so the pre-political right of expression must be guaranteed), to organize themselves, and be able to participate in the making process. They should also be allowed to make an in put. As so often is unfortunately the case, it should not be a process in which the elite rather condescendingly 'educate' the mass. Mattei (1995:9) refers to the process of popular discussion the Eritrean constitution makers had with the people on the draft prepared by the Commission as one in which the former were teaching the latter in a manner that is patronizing . Instead, the popular discussion can be done in the form of seminars, workshops, symposia, etc. After such a discussion, a representative group might also discuss the document as enriched by the popular discussion before it finally submits it for adoption by a constitutional assembly or through a popular referendum that ratifies the document afterwards depending on the process agreed upon for the adoption and ratification.

Thirdly, the adoption of the draft document must be done by a body that is fairly representative of all the political actors and other stakeholders. Thus the election that leads up to the constitution of such a constitutive body, the mandate of such a body, and the degree of openness, freedom, and vitality with which such a body makes its deliberations are key to the making of the constitution. Such an institution may complete its task when it approves the draft submitted to it for deliberation. Or it may itself complete the process of constitution making when, by adoption of the draft, it also ratifies it, on behalf of the peoples of the country, as a final constitutional document. If the latter is the case, the members of the constitutional assembly become the founders of the polity. But countries may choose to require a further step.

The fourth stage then will be ratification through popular referenda or through the interposition of the legislative assemblies of the units that constitute the larger polity intended to be established through the new constitution. The latter happens if there are units that ante-date the constitution or the polity that the constitution seeks to create.

For the content of a constitutional text, drafters might be dependent on a diverse array of sources. The easier choice, but not necessarily the most appropriate and the most effective, will be borrowing and transplantation from other countries or the rich realm of international (human rights) law ${ }^{2}$. Note that borrowing and transplantation require a

2 In more recent years, the guarantee of fundamental (human) rights and freedoms is considered the sine qua non of legitimacy of constitutions as a result of which constitution making has to be mindful of them. Borrowing is the trait of the 'have not's: laws flow from dominant systems to less dominant ones. Or so says Alan Watson (1993). 
rich capacity to adapt the "borrowed" values, institutions, doctrines, etc. It also requires compatibility of the host country to the borrowed 'commodity'. Note further that Pierre Legrand (I997: III) argues that transplantation is impossible as we can't borrow the mindset, or the mentalité, even when we can transpose the norms, the institutions, and the concomitant procedures, doctrines, etc. This guarantees international recognition, legitimacy, and the possibility of securing funds (in the form of loans or otherwise). The other choice is to look to traditions of a country, the only problem being that if a polity wants to break with its traditions and chart a new track for itself, there is little we can take from the tradition. A yetother option is to look into the experiences (of the immediate past) that led to the process of constitution-making. This option of course runs the risk of excessive politicization of the document that will be produced. Often, an eclectic combination of choices is done without being glibly syncretistic. But it needs to be underscored that, regardless of the choice that is finally made, there is a need to look into the social, moral, cultural, political, and even religious fabric of the society to reflect on what should (not) go into the content of the constitution. It is also necessary that we see if the economic facility to back the system is available, or will be available in the long run.

Needless to say, one also needs to make an assessment of the context in which the constitution is anticipated to operate so that it will not be culturally alienated. Care is required when addressing the question of how the constitution deals with traditional sources of legitimacy (such as religion, tradition, or even force), especially in polities where the legal system manifests layers of legal orders (such as the rule of traditional law - alias customary law - , the rule of political law, or the rule of professional law). I am indebted to Mattei (1997) for this classification of legal families. According to Mattei, the rule of professional law is that which is dominant in the Western legal tradition where the legal professionals (judges, lawyers, etc) "control" or influence the politicians. The rule of political law is one that is dominant in the developing countries, countries in transition, where the politics subordinates the law and the former "controls" or influences the latter. The rule of traditional law is one in which religious or customary traditions dominate. Most countries of the East such as Japan, China, and large parts of Africa and Latin America are in this category.

As was signalled earlier in the article, constitution making is more than concocting a constitutional text. Indeed, as Elazar (1994: 13) says, "constitution-making involves the embodiment of the constitutional traditions of the body politic in appropriate binding rules of the game that properly reflect the polity model, basis, and socio-economic distribution of power." This impels us to be very methodical about the choices we make as to the models of the polity and its constitution, the processes of its making, the substance of its content, and the context in which it applies.

It is important to note that if the process is flawed, the content is hardly looked into. Often, the "baby is thrown with the bathwater". In such circumstances, as I shall argue later, original legitimacy becomes weak. Derivative (or earned) legitimacy - that which is derived from content cum practice (hence derivative) - alone comes to the aid of saving the system. Original legitimacy is absent often because makers do not enjoy a perfect 
'constitutional moment'. Often transitions are tumultuous, full of turmoil (perhaps the last stage of an age-old conflict, or war) marked by instability, confusion and depression, poverty, foreign occupation, international pressure, a rigid time line, etc. Depression can occur, mainly because of the division and polarization between the victors and the vanquished. Foreign occupation is the case, for instance, in the example of Iraq since 2004, the time the new constitution has been in the making. The transition may also have a deadline at which time it must move from being a theoretical document to being a new constitution that fills the void. One recalls the transition in Ethiopia to see how the two year time limit for the transition has pressurized the process of constitution-making from 1992 to 1994 (see Lyons 1996 ).

In these moments, leadership is crucial. Factions abound. Ambitions are loudly voiced. Political push and pull seems to be commonplace. The passing and the abiding are indistinguishable. Sobriety is rare. Social 'adolescence' tends to be on the rise. The orthodoxy of the victors seeks to gain ground to establish itself as the hegemonic idea in the country. The orthodoxies of the vanquished seek to survive often subverting the new and threatening that, without it, the nation collapses. It is thus important to note that constitution-making, happening as it does in imperfect moments (not to say in the worst of times), is a difficult process that demands creativity, skill, and patience. More importantly, it is a non-ideal time during which an attempt is made to embellish the text by taking note of the crisis situation it is emerging out of while also keeping an eye on designing a project to build a 'more perfect' polity. In fact, one cannot help thinking about the challenge of law being caught between apology and utopia. For the tension of this type in international law, see Koskenniemi (2006).

\section{Constitutional Practice: What Factors Determine it?}

Constitutional practice, the process of applying a constitutional text to 'real life' situations of a polity, may generally be viewed as the function of the factors that went into the constitutional design. But it is more. Often, it is assumed that ratification of a constitutional text spells the culmination of constitution-making process. However, in reality, it is not hard to realize that constitutional practice is partly an extension of constitutional design. In a sense, it is a continuation of the design. For in the process of implementation, constitutions are interpreted, reinforced, reinterpreted, and re-created. (In a sense then, the making of a constitution is a continuous process that never ends.)

The extent to which the design is 'right' of course will have an impact on what the constitutional practice will turn out to look like. If there is a basic agreement on the question of who the makers are (and the extent to which they are representative of the peoples, actors, and groups of a country), on what process the making ought to go through, on what the core contents of the text of the constitutions should look like, and on the extent to which the text has to resonate well with the socio-cultural moorings or contexts, then there will be the likelihood that the process of constitutional practice will go smoothly.

But what are the factors that determine constitutional practice? An interplay of multiple factors contribute to a good constitutional practice. Legitimacy and the 
entrenchment of constitutionalism can be mentioned as one of the most important factors. The existence of a sufficient degree of separation between the constitution and day to day politics, the dominance of the idea of autonomy of law and politics, the existence of a vibrant positive constitutional culture, the socio-cultural relevance of the content of the constitutional text, the degree of effectiveness and efficiency of constitutional institutions, efficacy (compliance by officials and obeisance by the majority of the public), etc contribute to the implementation of constitutions.

But all these factors can be arranged under the three rubrics of 'legitimacy', 'constitutionalism', and 'efficacy'. The term legitimacy connotes acceptability. It is about popular recognition and acceptance. It refers to the belief among a large number of people that the constitutional text needs to be obeyed by all (see Shively 1999: 136). As Wiarda (1993: 87 ) says, in relation to legitimacy of governments or their exercise of power, it is "a wide spread acceptance" of a system. Often, regime legitimacy may be rooted in the political culture of a polity, the "community-held beliefs, feelings, and values that influence political behaviour" which in turn depends on "the knowledge of the way in which the system operates, its personnel and its policies." (Curtis I985: 6). Traditionally, the three types of legitimacy that Weber (in Rehinstein 1954) identified as "traditional", "charismatic", and "rational", are considered to be by far the most expressive of the sources of regime legitimacy.

Shively (1999: 137-138) identifies four major sources of regime legitimacy, namely the capacity of the system to deliver results (e.g. physical security, security from external aggression, economic security, national pride, etc); habit of obedience (not knowing how to behave otherwise, especially when the country is new and loyalty to the founders is the norm); connection to the religion or ethnicity of the majority of the people; or the procedure of decision-making (e.g. democracy). Legitimacy of a system is also tied to consensus. Consensus, "acceptance of a given political system" - addressed as it is to "the basic rules that define, establish, limit, and channel political power" - converts "power into authority, and the legal enactments emanating from the government into legitimate orders." (Brown \& Macridis I996: 86).

There are varying conceptions of legitimacy. Often, these varying conceptions have led to confusion in relation to the term. Four conceptions of legitimacy may be readily identified: legitimacy as a democratic process; legitimacy as a legal authority; legitimacy as reliability (to produce a just and fair decision); and legitimacy as based on a public reason rooted in shared common humanity. The lack of clarity that surrounds these conceptions and the fact that the concept of legitimacy itself is undertheorized has contributed to the confusion. The many misconceptions and the confusion aside, the legitimacy of constitutions remains an issue of key significance.

Constitutions' legitimacy is assumed to emanate ultimately from the sovereignty of the people who, at least theoretically, are the makers. But more particularly, what makes a constitution legitimate? We now turn to this question. The legitimacy of a constitution is rooted in moral, legal, and sociological foundations. Richard Fallon Jr. (2005), for example argues that while the legitimacy of a constitution is often sought in the legal propriety 
of its making, a fuller understanding can only come when we explore its sociological and moral bases. As Bilgin (2007) argues, "[l] egitimacy of a constitution... requires a genuine social acceptance, where the relevant public reveres and honours both the political intention and expression behind the constitution and legal forms and foundational institutions instituted by the constitution." One can thus maintain, concurring with Calvert (I985: 35), that a constitution's legitimacy comes from its appropriate framing, the authority it commands, the justification it carries, the legality it endows, and the consent it refers to.

Constitutions' legitimacy is a matter of degree, not a matter of absence or presence. Shively (1999: 137) argues that such is the case for regime legitimacy. Over time, legitimacy might have its own ebb and flow. Those constitutions which are born in the context of an overwhelming consensus that engendered the participation of all sectors of the population, and have as a result developed content that is entirely compatible with the sociocultural and political context might have a strong original legitimacy. It is often said that no constitution obtains such a strong legitimacy in its formative years. It takes a while until the honour, reverence and allegiance that converts a constitution into a 'scripture' of a sort emerges. But constitutions also gain a legitimacy that emerges as their clauses are implemented to the satisfaction of most of the members of the polity. This kind of legitimacy is an earned legitimacy, legitimacy that is derived from a consistent application, and so one derived from fidelity to the text (hence derivative legitimacy). This implies that we cannot take legitimacy for granted. While those constitutions with a deficit of original legitimacy might earn a derivative legitimacy over time, it is also possible that those with strong original legitimacy might gradually lose it when the constitution's authority is compromised through defiance that goes unpunished.

The second important category of factors for an effective constitutional practice, which is closely related to legitimacy, is the entrenchment of constitutionalism. Broadly, constitutionalism can be viewed as a principle that limits the exercise of power through the instrumentality of a constitution that serves as a constraint. See Murphy (2000) on the meaning of constitutionalism and its difference from constitutionism, which is a mechanical adherence to a constitutional text. One also notes the fact that constitutionalism is not synonymous with constitution although the former often includes the latter; see Jain (1994: 3-4) where he says: "A country may have a 'constitution' but not necessarily 'constitutionalism"”. Constitutionalism is more than a dogmatic application of the letter of the constitution. Being also rooted in the wider culture, it requires a mindset of a citizenry who assert their rights under the constitution to tame power; a belief in one's constitutional institutions; and a trust in the fundamental fairness of the constitutional process. For this, apart from the 'right' institutional and structural framework, civic education (which political scientists refer to as 'political socialization') is of help. Separation of powers, rule of law, judicial independence/autonomy, human rights, separation of state and political parties, free media, and others are said to constitute the structural/institutional requirements of constitutionalism. Khan \& McNiven (I990), Curtis et al. (I985) and Shively (1999) all refer to the concept of 'political culture', pointing to the work by 
Almond \& Verba (1963) who in turn classify cultures into 'parochial', 'subject', and 'participant'. The extent to which constitutions are divorced from political action (which they seek to control and regulate), and the bigger issue of the autonomy of law from politics is an aspect of the extent to which constitutionalism is entrenched.

The third category of factors relate to the efficacy of the constitution. This deals with the capacity to command obedience. This, to a large extent, depends on the strength of the constitutional (and generally, state) institutions. The degree of autonomy, politicalneutrality, and effectiveness of such institutions as constitutional interpreters (be it a court or otherwise) are all very important. These things in turn depend on (and contribute to) the extent to which the constitution has an exerted, i.e., operative, authority, as opposed to that which is merely asserted. The extent to which officials are willing to comply with constitutional norms and the people are willing to obey them is key to the efficacy of the constitutional system. But one now notices how obviously this points back to the issue of legitimacy and constitutionalism.

\section{The Making and Legitimacy of the Ethiopian Constitution}

Ethiopia has had four major written constitutions in the 2oth century alone. This is without considering the Draft Constitution that was prepared after revising the 1955 constitution on the eve of the 1974 revolution which overtook the process, and the Transitional charter of I99I which, being the "supreme law of the land"(art I8), served as the interim constitution for the time from I991-1995. This is also without considering the set of public law legislations that governed the pre-constitutional days of the Derg (i.e.1974-1987). The first two written constitutions (the second is supposedly only a revised version of the first) of I93 I and 1955 were both Imperial grants to the ("beloved") people of Ethiopia. The third, the 1987 PDRE Constitution, was more like a revolutionary manifesto with socialist overtones in its fundamental values and was, at least theoretically, made by the "Working People of Ethiopia." Indeed, the Preamble of the PDRE Constitution opens with the words: "We the working People of Ethiopia,..." (see Negarit Gazeta 1987). Ethiopia is an old polity principally formed through military conquest and the incorporation of vast lands with diverse peoples with equally diverse linguistic and cultural identities into the Ethiopian empire. ${ }^{3}$ As such the source of legitimacy of state power in the country has never been a written constitutional text. It is often said that the key sources of legitimacy in Ethiopia's past were force (conquest, military expansion), religion (i.e. Orthodox Christianity), and tradition (i.e. 'right' genealogy) (Mattei 1995). This is also in line with the official titles of the supposedly "Solomonic" Ethiopian Emperors which, roughly, are as follows; "Conquering Lion [marking might, or force] of the Tribe of Judah [marking genealogy and tradition], Elect of God [marking the vital importance 
of religious anointing to qualify for the throne], ... [the name], King of Kings, Emperor of Ethiopia." Hence, the importance of genealogy and tradition. Both in the 1974 revolution and in the drift to a half-hearted liberal constitutionalism in the I990s, there was a declared intent to break with this past and set the country on a 'republican' road with a socialist and a liberal touch, respectively, to the democracy that was to be experienced.

The 1995 constitution (and the Transitional Charter that preceded it) was especially keen on bringing about a rapturous break with the hitherto dominant mode of organizing the polity as a centralized unitary form of government with no recognition of the ethno-linguistic groups that constitute the demographic whole of the Ethiopian polity. It was nothing less than a total restructuring. Perhaps it is in recognition of this restructuring that Wendy James and Donald Donham entitled their re-edited book, Remapping Ethiopia: Socialism and After (2002). Apparently prompted by this, Gunther Schlee (2003) also echoes this restructuring. This is not to suggest that there are no critics who say little has changed at all, or if there is any change, it is one for the worse. See, for example, Minassie Haile (2005). This was a restructuring, indeed, mainly because of the recognition of the ethnic diversity and the valorisation of the same by converting the old oppressed ethnic groups into sub-national sovereignties. This was done by primarily guaranteeing their right to self-determination in the Transitional Charter in I99I (article 2) and by extending sovereignty to them in the 1995 constitution (art 8) in addition to reaffirming their right to self-determination (in the now famous/ infamous [?] art 39). The process culminated in the adoption of a written constitution that envisages the establishment of a federal, secular, human-rights sensitive, democratic republic that is constituted of explicitly ethno-nationalist sub-national units. This can be gathered from the constitution's provisions: art I (on the name and its federal structure), art II (on secularism), art 8 (on democracy), arts ro andi $3-44$ (on human rights), and others. But what does the process that led to the constitution look like? How was the Ethiopian constitution of I995 made? What kind of legitimacy does it command? We now turn to these questions.

Historical Backdrop. The making of the Ethiopian constitution had its beginnings in the transitional period which lasted from I99I to 1995. During this period public life was governed by the Transitional Period Charter, a brief document of no more than 20 articles which served as the interim constitution. The Charter was more like a pact negotiated between ethno-nationalist liberation fronts that, through armed struggle, toppled the regime that was in power until May I99I. As such, it was primarily a peace document, an accord. But it was also more than this. It aimed at rebuilding the country and restructuring the state democratically (see paragraph $\mathrm{I}$ of the preamble). It also sought to mark a break with the past and usher in a new chapter (of respect for human rights, equality, and self-determination, rescue from subjugation, etc) in the history of Ethiopia (see paragraph 2 of the preamble). The establishment of peace and stability, the ensuring of just peace, the dismantling of the repressive institutions of the preceding regime, and the urge to transit to a democratic order were the major goals intended to be achieved through the Charter. This evokes the memory of the twin efforts at de-nazification and democratization of West Germany on the aftermath of WWII as a prelude to the making of the Basic Law (Kommers I985). 
The Charter readily recognized both individual rights and freedoms (under art $\mathrm{I}$ ) and group rights (of "nations, nationalities, and peoples") to self-determination (art 2). The Universal Declaration of Human Rights (UDHR) was directly endorsed. Civil and political rights such as freedom of association, expression and assembly were explicitly mentioned and guaranteed (art I). The now divisive issue of the right to secession was tempered by conditions that need to be fulfilled before a group can assert its right to "independence". (Art 2(3)). The conditions are denial, abrogation, or abridging of the rights to identity, culture, history, language, and self-administration. In the words of the Charter $(\operatorname{art} 2(\mathrm{C})$ ), the right to independence is exercised "when the concerned nation/nationality and people is convinced that the above rights are denied, abridged, or abrogated."

After setting the foreign policy principles of the transition (arts 3-4) and acknowledging the right of sub-national entities to directly forge a relation with foreign relief institutions (art 5), the Charter ventured to form a government with a unicameral legislature called "Council of Representatives [hereinafter COR] (with a maximum of 87 members composed of liberation fronts and other organizations) and an Executive organ (made up of a Council of Ministers and a Head of State acting as a Chairman of the Government) (arts 6-9). Thus a quasi-parliamentary government was set up. The COR had the power to make laws and "oversee the work of the Council of Ministers" (art 9). This suggests the paramountcy of the COR thereby rendering it sovereign. This, however, is tempered by the strong power asserted, de facto, by the Chairman, who officially is 'The President' of the country. More importantly, the Charter envisaged the establishment of a Constitutional Commission [hereafter Commission] entrusted with the task of drafting a constitution (arts IO-II). Thus the Commission was to prepare the draft and submit it to the Transitional Council of Representatives, who on adopting it, was to present it to the people for discussion. The final draft that is prepared after such a popular discussion was to be adopted by a constituent assembly to be elected for this very purpose (but in accordance with the provisions of the final draft of the constitution) (art II).

The Charter went on to state that the transitional government will engage in the rebuilding of war-ravaged infrastructure (art $\mathrm{I}_{5}$ ), according "special consideration to hitherto neglected and forgotten areas" (art 16 ), and making efforts to dispel inter-ethnic mistrust and hatred (art I7). The Charter also had arrogated supremacy unto itself (art I8) thereby making itself an interim constitution of a sort. The government formed through the Charter oversaw the drafting of the constitution by statutorily forming the constitutional commission in 1992. The Constitutional Commission Establishment Proclamation No. 24/1992 was instrumental in this regard. It is interesting to note, incidentally, that the Charter was not strong on the matter of courts, their competence, and their role in managing the 'constitutional' equilibrium and that of regional self-governments. With regard to the 'constitutional' equilibrium there is only one sub-provision for courts in art $g(f)$ of the Charter which reads as follows: "The council of Representatives shall...provide for the administration of justice on the basis of the Charter; the Courts shall, in their work, be free from any governmental interference with respect to items provided for in Part One, Article One of the Charter [i.e., civil and political rights of individuals]." This clearly says little, if anything, on whether 
the courts have the power to engage in 'constitutional' interpretation. Note that it cannot adjudicate cases related to the right to self-determination (under article Two). The matter of regional self-government was legally dealt with later in the "National/ Regional Self-Government Establishment Proclamation No.7/1992". The Charter also omitted the issue of charter interpretation. Of course, for a constitutional instrument with a modest objective (that of primarily establishing peace and stability and charting out the route the transition is to take), that should not be taken as too big an omission.

The Making of the Constitution. The process of the making of the 1995 constitution was principally guided by the provisions in the Transitional Charter. According to the Charter:

"The Council of Representatives shall constitute the Constitutional commission to draw up a draft constitution. The Constitutional Commission shall submit to the Council of Representatives the draft constitution."(Article II)

"Upon adoption of the draft constitution by the Council of Representatives the constitution shall be presented to the people for discussion. The final draft shall be presented for adoption in the constituent assembly to be elected pursuant to the final draft of the constitution."(Article I2).

These two provisions guided and permeated the constitution making process in Ethiopia. One notes that the issue of the composition of the drafting commission was not detailed in the Charter. One also notes the important role the COR is anticipated to play in the deliberation on the constitutional draft, in addition to its role of establishing the Commission, deciding on the commission's budget, and overseeing its activities.

In 1992, the Constitutional Commission was legally established. Proclamation no. 24/1992, alias "Constitutional Commission Establishment Proclamation", was adopted by the COR. Physically placed in the premises of the Institute of Ethiopian Nationalities (as per article 3) - one cannot help but to note that this was also the place where the PDRE Constitution of 1987 was drafted, and speculate on whether there is more continuity than we normally assume - the Commission had the mission of preparing the draft, submitting the same to the COR, presenting the draft as adopted by the COR to the people, incorporating the comments in the final draft as may be deemed necessary, and finally submitting the final draft to the Constituent Assembly (art 4). The tasks (under art 5) included drafting the text, conducting seminars, symposia, and educational discussions (perhaps with a view to creating the 'festive mood' that attends a 'constitutional moment'), disseminating the draft constitution to the public, gathering comments (especially from the regions and districts), explaining the draft to the public in the course of the discussions, preparing the final draft, submitting periodic reports to the COR, and others. It is interesting that art 5(5) says that the commission has "to receive comments from national/regional and Woreda councils on the draft constitution". This was perhaps meant to make sure that the exercise is was not going to take merely a top-down approach. Moreover, the Commission was given the mission to prepare the draft "in con- 
formity with the spirit of the Charter" (art 4). It was obvious that the constitution was meant to be an instrument of advancing the aspirations of those who negotiated the Charter. To that extent, then, it was the extension, a natural historical outgrowth, of the Charter.

The Commission was organized in such a way that it had a 29-member General Assembly (GA), an Executive Committee, and various other (expert) committees (art 6 ). The composition of the GA was as follows (as per art 7): 7 members from the COR, 7 members representing various political parties, 3 members from Trade Unions, 2 members each from three professional associations (of Teachers, Lawyers, and Health Professionals ${ }^{4}$, 3 members from the Ethiopian Chamber of Commerce, and 3 members representing women. With regard to the representatives of women, it is unclear as to how, and from where, they were to be selected. It was not clear if political parties represented in the COR were also to be part of the GA thereby doubling the representation of the dominant party in the COR. The GA was granted the powers and duties vested in the Commission (art 8). So the GA was a proxy for the Commission. The Chairs (both the Chief and the Deputy) and the Secretary of the GA were to be appointed by the COR, and, indeed, were so appointed.

Steps in the Making. Asis the case wherever constitution-making is considered, the making of the Ethiopian constitution underwent the stages of drafting, deliberation, adoption, and ratification. More or less in a manner the proclamation dictates, the drafting process was accomplished in the Commission. In the Commission, as observed by Meaza Ashenafi (2003):

"debates were lively. The chairperson of the Commission encouraged decisions by consensus, though it was not always possible to reach a unanimous decision. The diversity of the Commission members meant that a great number of interests were represented. Informal lobbying and negotiations were part of the process. Nonetheless, the Ethiopian Peoples' Revolutionary Democratic Front (EPRDF), the ruling party, always dominated when an issue came to a vote, as it had the largest delegation." 5

In the course of producing the draft, the Commission also consulted a large number of foreign and local experts. In an attempt to benefit from comparison, other countries' constitutions were also referred to (Ashenafi 2003). Concept papers that outline various alternatives (of principles, institutions, and systems of government) were prepared and disseminated to the public for discussion (Ashenafi 2003). This effort was often aided by Inter-Africa Group (IAG), a Civil Society Organization active in the process. The IAG helped organize a number of workshops and symposia and published the papers presented in the course of the proceedings. Nevertheless, Ashenafi (2003) concludes, "this

One wonders why only these three professional associations are singled out for participation in the constitutiondrafting process.

5 Meaza Ashenafi was an associate (albeit informally) of one of the technical sub-committees (or committee of experts) at the time of the drafting of the constitution. Hence, this information on the inner workings of the Commission. 
should not give the impression that the process was fully participatory. Those who were not sympathetic to the transitional government and were dismissive of the whole process did not take part in the consultation; they believed that participation would be "legitimizing" the process. Another group, which was not politically active, was not interested." Ashenafi is not clear as to which ("other") group was uninterested. The point stands, however, that the process was not fully participatory.

In a similar vein, James C.N. Paul observes that

"there was little meaningful public participatory debate, especially debate focused on devolution versus ethnic federalism, let alone sovereignty or self-determination. [...], opposition parties withdrew. Instead of debating the content of the constitution, they denounced the legitimacy of the whole project. Just as the EPRDF controlled the Constitutional Commission's work, so it controlled the election, and then the deliberations, of the Constitutional Assembly." (Paul 2000: 189).

Paul also refers, albeit only tangentially, to the fact that, on assumption of power, the TPLF was instrumental in "establishing an essential foundation for a federal constitution, creating de facto one-party rule, marginalizing Amhara and Oromo opposition, and liquidating the Eritrean problem." (Paul 2000: 187). The issue of the exclusion of the numerically dominant Oromo and Amhara groups from the constitution-making process is more boldly spelt out by Ugo Mattei (I995: II4) who points to the weak popular support for the constitution among these groups. In his own words, he says, "none of the political and ethnic forces which make the opposition to [...] (EPRDF) had participated in the Constitutional making. All opposition parties, most importantly, those representing the Amhara and Oromo groups ( 38 and $35 \%$ respectively) withdrew from the electoral competition. The new constitution is therefore supported politically and ethnically only by the Tigrayan minority which counts less than I0\% of the population." Paul (2000: 189) also observes that "in view of the constitution's content, it seems regrettable that the processes for making it were so flawed". It is interesting to note, as shall be argued later, that the content of the constitution - in spite of the "flaws" associated with the making is what warrants the project of redemptive constitutional practice.

The draft was subsequently presented to the COR in 1994, and there the first phase, the phase of drafting, was completed. At the COR, there was a lengthy discussion on every provision of the draft for almost a month. There is, in fact, a voluminous body of compilations of the minutes of the meetings of the COR on the constitution for those of us who would like to learn about the substance of the discussion and about who said what. The details described rather copiously, I assume, are rather staggering. Most of the sessions of the discussion and the (at times spirited) debates were nationally televised. The discussion was informative in many ways. To most of my contemporaries, there was much more fun than might be expected of something that determines the destiny of the polity for years to come. After the draft was deliberated upon and was eventually adopted by a majority vote in the COR, it was presented by the Commission to the public. 
Thus, discussions were staged in the Kebeles. In Addis Ababa, school premises were used for the popular discussions. The turnout was low. Interest was at its minimum for a constitutional deliberation. (This is in part based on personal observation of the situation in the Summer of i994). At the end of the public discussions, the second phase, the phase of deliberation, was closed although a new discussion, meant only for adoption, is yet to start in the Constituent Assembly. Regarding the process of the discussions that led to the adoption of the constitution, John Markakis (2007: 58) observes that it was "largely unanticipated", and followed "a brief but intensive period of publicity to mobilize support." He goes on to say that, because the process was rushed, "it is fair to say that not many Ethiopians who live in the countryside have a clear notion of what federalism means, or had the opportunity to express an opinion on its merits. There was simply no time to form a national consensus on the legitimacy of the new political system."

The third phase, the phase of adoption of the draft constitution (as enriched by comments from the COR and the people, much less by the latter), started immediately upon the election of the members of the Constituent Assembly. The discussion in the Constituent Assembly was also lengthy. The discussions ended with the adoption of the final draft submitted by the Commission to the Constituent Assembly apparently after incorporating the comments in December 1994. With it ended the third phase and the formal process of constitution-making in Ethiopia. One can take the adoption by the Constituent Assembly as a form of ratification of the constitution by the people albeit indirectly through their representatives. Consequently, but unlike other systems, there was not a popular ratification of the constitution through referendum. Ratification through popular referendum, it is argued, would bolster the degree of popular support the constitution now commands. But given the general lack of the festive mood attendant to constitutional moments, and the fact that the process was rather speedy, as Markakis (2007) observed, one wonders if the referendum, apart from allowing one more opportunity for participation, would result in a different content.

Who are the makers? Formal legal analysis aside, who are the real makers of the constitution? Who are the key actors involved at the drafting, deliberation, and adoption stages of the constitution-making process in Ethiopia? The question of who, the 'political question' (à la Rorty 1996) is important in constitution-making perhaps because, as Elazar (1994: 14) says, constitution-making is the "pre-eminently political act". The answer to the 'who' question requires substantive research into the identity, the political affiliation, and the educational orientation, etc, of the members that constituted the GA of the Commission, the COR, and the Constituent Assembly. This has not been undertaken in the research leading to the writing of this article. But one can conjecture as to the political-party composition of the COR and the Constituent Assembly; at least one can state without exaggeration that the EPRDF was a dominant partner in both institutions, and so in the entire process (see Ashenafi 2003 and Paul 2000). This is partly the cause of the discontent seen among some political corners. Not entirely unexpectedly, the discontent undermined legitimacy. 
Content of the Text. The constitution that was so adopted, the FDRE constitution, came into force in 1995. When it did, it set up a federal polity that imitated the trend to decentralization during the Transitional period. True to the "spirit of the Charter", the rights of "nations, nationalities, and peoples" to self-determination were reaffirmed in article 39 of the FDRE. "Nations, Nationalities, and Peoples" were granted sovereignty (art. 8). It sought to redesign the symbols (e.g. the name, flag, and anthem) in such a way that they resonate well with the new dispensation. Article I says: that "Federal Democratic Republic of Ethiopia" is the official name. Article 3 (2) requires that the emblem reflects the hope of 'nations, nationalities, and peoples' and religious communities to live in equality and unity. (The stress on equality and unity can, in retrospect, be seen as an attempt to address the concerns of both the South and North in Ethiopia - the South generally specializing in the rhetoric of equality and the North generally in the rhetoric of unity. This division of rhetorical specialization is explored further in Regassa (2007). Art 3(3) declares that states, too, can have their own flags. Art 4 requires that the national anthem be reflective of the common destiny, the ideals of the constitution, the commitment to live in a democratic order. The constitution recognized equality of all languages but maintained Amharic as a working language of the Federal Government (art 5). In this, the constitution marked more continuity than change, as already in the PDRE Constitution of 1987 , at least formally speaking, all languages were granted equality and Amharic was the working language all over the country. But note also the difference between Amharic being the working language all over the country but its also being the working language of the Federal Government. For a detailed discussion on this see Degefa (2008a, b). The constitution enshrined the principles of ethnic sovereignty, constitutionalism and constitutional supremacy, human rights, secularism, and transparency and accountability of government as the basic pillars of the constitutional system (arts 8-12). It recognized human rights extensively (arts 13-44). It established a federal political system of nine units and an autonomous city administration of the federal capital (arts 46-52). It established a parliamentary system of government (arts $45 ; 53-68$ ). It organized a strong executive body composed of a Prime Minister, Council of Ministers, and Ministries who operate under a sovereign parliament and a President who has a predominantly ceremonial role (Arts 69-77). This is not to underestimate the significant role. of the Office of the President in filling potential power vacuum in times of constitutional/electoral crises that leads to the dissolution of Parliament (Regassa 2007). A largely non-legislative upper house in charge, among other things, of constitutional interpretation (aided by a Constitutional Inquiry Council) was established (art 62; 82-84) - this was perhaps an Ethiopian novelty in the realm of contemporary constitutional design. A three-tiered, dual system of federal and state judiciaries was set up (arts 78-8I). A set of policy objectives and directive principles that serve as the conscience of the system were also incorporated in arts 85-92. Provisions on emergency powers (art 93), finances, expenditure and revenue responsibilities (arts 94-100), and amendment (104-105) were included. The ideally non-partisan institutions of the Auditor General (IOr), the National Election Board (ro3), Population and Census Commission (ro4) were all established. 
In many ways, the constitution is like other constitutions of the world. Its major distinctive features are its recognition of secession, its unique process of constitutional adjudication, the use of ethno-linguistic criteria as the predominant basis of carving out the states that constitute the federation, the little, if any, involvement of the upper house in legislation, its ready recognition of indigenous and religious law systems on matters related to personal and family issues (see Regassa 200r). Jon Abbink (1997: 166) maintains that "The main clauses of the Ethiopian Constitution, which make it certainly a very original document, refer to ethnicity and the federal order." While, indeed there is a degree of boldness and novelty (much more the former than the latter) to the constitution in this regard, one notes that the former Soviet Union and the Federal Republic of Yugoslavia had a more or less similar arrangement - and to this extent, the originality fades.

Mattei (I995: II2) lays the charge that the constitution is "a new wall made of old imported bricks" He argues that, regrettably, squandering the opportunity to be "a frontrunner of a new and ripe African Constitutional tradition", Ethiopia attempted to "import the strongest [i.e., American] version of the Western conception of the rule of law." Moreover, he argues that if we stamp out all the references to Ethiopia in articles $\mathrm{I}, 28$, $32(\mathrm{I}), 39,40,4 \mathrm{I}, 44,47$, etc, it will be revealed that the constitution can be a model "apt to fit all [...] realities" (Mattei 1995: I15). Furthermore, in a manner that smacks of condescension, he comments that the constitution evokes the implication that there is an intellectual dependence on the West and a blunt form of cultural imperialism that pervades the state of affairs in post-colonial Africa (Mattei I995: II2, II3, II8). Consequently, he sees nothing new in, or autochthonously Ethiopian about, the constitution except the provisions on prohibition of applying the statute of limitations for offense of genocide (art 28) and the right to secession (art 39(I)). He asserts that the rest of the corpus of the text is a mere transplantation (from the US, UK, Germany, Scandinavia, and international human rights law). He is thus sceptical of the applicability of such a transplanted law in a legal and cultural context that does not resonate well with the 'imported' values. In fact, that they do not resonate well with each other is more an assumption than an empirically validated claim. Mattei (1995: 6-7) refers to the tolerance and even formal recognition of customary and religious laws in arts 34(5) and 78(5), respectively, as "rather braggy" because the power between official and unofficial law is not balanced enough to allow the latter to be effectively applied.

Mattei's criticism of the content of the constitution as inappropriately imported can be countered by, among other things, reference to the fact that modernity has had a disproportionately imbalanced geographic reach as a consequence of which, to a large extent, there is the lure of modernity among the countries of the global South. In these latter countries, borrowing is thus ubiquitous. Given that centuries of colonization in the wider context of Africa and decades of modernization-driven imitation of the West in Ethiopia, most of the autochthonous traditions are either stunted or on the wane, receding into non-existence; see Zoethout et al (1996) for reflections on the dilemma of constitutionalism in Africa, and also Legesse (2006) for a tightly argued defence of the thesis that there is an autochthonous constitutional tradition in Africa typified by the Oromo of Ethiopia and the Horn. In the course of the colonial encounter, "customary" laws are often viewed 
as the underdeveloped "primitive", "other" laws that are anachronistic and unfit to the age of political correctness in constitution writing. (However, Markakis (2007: 52) identifies political correctness as the hallmark of African constitutions adopted in the i990s.) This state of affairs is further reinforced by the fact that constitution-makers hardly enjoy a perfect 'constitutional moment' as a result of which borrowing - conscious or unconscious - comes in as a useful aid. If constitution-writers are to be blamed, therefore, they can be blamed not for borrowing, but for borrowing inappropriate principles, institutions, and structures or doing so when the circumstances in the host country do not warrant it. Adoption and adaptation of other systems in a way that fits in the host system and serves the purposes that the latter seeks to achieve is not only practically necessary but also morally appropriate. Mattei's indication of the excessive (and in his view unjustified) borrowing, coupled with Markakis's list of the hallmarks of recent years' African constitutionalism driven primarily by political correctness, alerts us to the dangers of crafting constitutions of merely academic significance. The hallmarks of the new constitutionalism sought in Africa, according to Markakis, include a small, mainly, administrative state, free market and privatization, structural adjustment, foreign funded civil society, election, multipartism, weak executive accountable to parliaments, innumerable human rights institutions, and (sometimes absurd) political correctness (that forces the state to recognize the rights of minorities, women, children, the aged, the sick, the disabled, etc and to provide for services such as health, education, employment, and to care for the environment) that does not resonate well with the immense economic challenges the states in Africa languish under (Markakis 2007: 5I-52).

It is clear that the Ethiopian constitution, judged by the criteria discussed above and seen in the light of the practice following its adoption, makes Mattei's claims rather exaggerated and empirically unsupported.

Legitmacy. As has been hinted at earlier on in section three, legitimacy can be assessed in the light of the constitution-making process, the content of the text, and the compatibility of the text to the context. The making process, which - as indicated earlier - was dominated by the EPRDF, has resulted in discontent among some political factions in Ethiopia. This discontent has affected the level of popular acceptability the constitution commands. The fact that there was little popular participation at the time of the deliberations (which can be explained by a number of reasons such as apathy; lack of knowledge among many members of the public; confusion which resulted from disillusionment with the Derg; uncertainty about who is the genuine representative of the peoples; lack of a credible leader behind whom to rally; fear of disintegration of the country; disaffection that resulted from difficulty of life that also stemmed from the dismemberment of the large national army; the sense of 'loss' of Eritrea after so many years of sacrifice in the past and with no say about the future in the present; economic difficulty; internal instability, especially after the withdrawal of the Oromo Liberation Front (OLF) from the pact that formed the Transitional Government (and the consequent despair that spread among many Oromos); the fall of ethnic politics into disrepute among the urban elites who still commanded immense cultural power (and the consequent silent withdrawal 
of engagement with the process); lack of consensus, trust, and toleration; etc.), may all have contributed to the lack of intense participation in the constitution-making process. ${ }^{6}$ The consequent lack of active engagement with the process must in turn have contributed to the lack of original legitimacy.

The content is not often debated. But at least among academic and some political circles, some provisions are raised as politically divisive and to that extent as rendering the legitimacy of the constitution contested. The recognition of secession (Art. 39 (I)), the adoption of ethnically oriented federal set up (the use of ethno-linguistic criteria of state formation) (Arts. 46-47), the fact that a political body, i.e., the House of the Federation, is the ultimate arbiter of constitutional disputes, and not the courts (Arts. 62 cum 82-84), the issue of state ownership of land (Art. $40(3)$ ), etc. are a few of these. Important to note is that political parties such as the Oromo Federalist Democratic Movement (OFDM) seek to see a Presidential form of government installed in the constitution. Others, such as the UEDF, seek the adoption of a proportional representation system of election. Some people also raise the issue of why the number of times the Prime Minister runs for office is not fixed in the constitution as important. Whether it is proper to allow forming political parties on ethnic lines is also raised as an issue to be recast, but I think this latter concern is extra-constitutional.

More often, the questions raised are about the lack of commitment to implement the constitutional values, principles, and rules. The alleged (factually true or merely perceived) violations of the constitution (often exemplified by acts that undermine human rights of, say, accused, arrested, detained, or imprisoned persons, or of the press) create an intense discontent. Such discontent emanates from the gap between constitutional law and constitutional practice, or between design and implementation. It presses the uninitiated citizen into disowning the constitution in toto thereby enhancing and deepening the sense of lack of legitimacy.

Irrespective of the fact that most of the values are imported ones, there is hardly a risk of cultural incompatibility that delegitimizes the constitutional system. What critics of transplantation (such as Mattei) tend to neglect is the changing reality of the host legal system, the fact that while there is a sub-culture of the rule of traditional law (in countries such as Ethiopia), the dominant culture at least in the formal-urban legal system and among the informed voting public is friendly to (if not enthusiastic supporters of) transplanted values such as human rights, constitutionalism, and democracy, etc. In the age of hyper-technologized flow of information and television, the lure of modernity should not be underestimated.

One needs to reiterate that legitimacy is a matter of degree, not of absence or presence. Its original form cannot be absolute. This is because no constitution galvanizes total moral, social, and legal acceptability at the time of the making. The reason is that there are no perfect constitutional moments that enable the makers to guarantee a perfect process, a totally perfect document that is agreeable to all, or that is perfectly in tune with 
the context of the polity. The fact that the constitution making enterprise is an inexorably political one makes the process contested, the content more of a compromise (and hence less than ideal), and the context disputed and subject to interpretation. Consequently, constitutions tend to start with a weak degree of original legitimacy that grows and expands through time depending, of course, on the extent of an entrenched and entrenching constitutional practice. This growing form of legitimacy is a derivative legitimacy that the constitution earns (hence, also earned legitimacy) in the course of post-adoption constitutional practice. Earned legitimacy is dependent, to a large extent, on the extent of fidelity of the practice to the text, values, and principles of constitution (Balkin 2007). To the extent that practice departs from the text, values, and principles of the constitution, "infidelity" sets in and to that extent even earned legitimacy is weakened. The result of weak earned legitimacy is disaffection of a higher order as it is the result of a lived experience that witnessed the failure to deliver a constitutional promise. While there is no gainsaying that the Ethiopian constitution had a weak original legitimacy, over time it has gained a degree of derivative legitimacy. One sign of this is the increasing involvement of many (opposition) political parties in elections over the years and the progressively broader participation of the public in the same. Since 1995 , more and more (opposition) political parties demonstrated willingness to take part in elections even when they were quick to point out that they have reservations on some clauses of the constitution. The climax of this progressive interest in constitutional engagement both of the parties and of the voting public is the election of 2005. Another sign is the growing number of cases of constitutional disputes submitted to the House of Federation and the Council of Constitutional Inquiry. The cases range from that of identity and self-definition to a quest for self-government, statehood, individual right to interpersonal equality and collective right to one's 'own' law (see Getahun Kassa (2007) for a selective review of the cases disposed of by the HoF). On the other hand, there is equally no denying that the practice has manifested a number of shortcomings that severely undermine earned legitimacy. For instance, there are numerous reports of unconstitutional violations of human rights, especially by international organizations. The post-election crisis of 2005 has also indicated that we need to make a conscientious effort not to backtrack on our constitutional commitments, as there is a lot about the legitimacy not to be taken for granted. Note, for example, that immediately after the electoral polls were closed on 15 May 2005, the prime Minister announced a one-month long (later renewed for another month) ban on public meeting and demonstration. The ban was not proclaimed in accordance with the emergency clause provisions of the constitution. The CUD, the opposition party that was then contending for power, took the case to court. The court referred it to the Council of Constitutional Inquiry (CCI). The CCI ruled that the measure taken by the Prime Minister - taken as it was to safeguard the constitutional order - was within the mandate of the Prime Minister and was as such was constitutional. See CUD v. Prime Minister Meles Zenawi (CCI/2005) for details; see also the reports of Human Rights Watch (2008) for examples of weak human rights performance of Ethiopia. More recently, the International Crisis Group (ICG) (2009) issued a report which is hardly flattering to Ethiopia's human rights performance. 
Consequently, owing to the lack of original legitimacy and the discontent created by the gap between the law and the practice (most notably in the realm of criminal procedural rights of accused persons, for example to appear before a court within 48 hours, or to bail, etc), there is a consequent weak exerted authority of the constitution which makes one wonder if the environment is conducive to constitutionalism. One also wonders, following the tack of Mattei (I998: I2), if "the armed men will obey the unarmed man", if the politicians will have a reason, an incentive, to obey the judges.

Constitutionalism, the "theory that accepts the necessity of ... limited government," (Murphy et al 1995: 3 ) is a device for taming government, even a democratic government (see also Sajo 1999: 49-68). It is often characterized by elements such as: a supreme constitution, independent judiciary with a power of judicial review, rule of law, separation of powers, checks and balances, fundamental rights, and others. The elements of constitutionalism that recur in the discussion on the subject also include, apart from those mentioned, due process of law binding procedure of law-making (Bo $\mathrm{Li}$ 2008: 2). Louis Henkin (2000) enumerates the following: I) Government according to the constitution; 2) separation of powers; 3 ) sovereignty of peoples (or democratic governance); 4) constitutional review; 5) independent judiciary; 6) bill of rights; 7) controlling the police; 8) civilian control of the military; 9) no or limited, state power to suspend the constitution or its parts. In a similar vein, Jain (1994: 4) gives us the following "principles and norms which promote constitutionalism in a country": a written constitution; independent judiciary with judicial review power; doctrine of rule of law; separation of powers; free elections to legislatures; democratic government; fundamental rights of the people; and federalism. Formally speaking, the Ethiopian system is marked by the existence of a supreme written constitution (art 9), a democratic government formed through elections (art 8 cum arts 54-60; 72-77), sanctity of fundamental rights and freedoms (art 10 cum arts 13-44), and independent judiciary (art 78). One readily notes the fact that none of the three elections held I995, 2000, and 2005 were reported to be entirely free and fair by all parties involved. The political campaigns that led up to the 2005 election were reported to be free in a manner that was unprecedented in the country's history but the post-election crisis that emerged along with the contestation of the results of the election marred the whole process. It also led to scepticism as to the prospects of a free and fair election hence forth. The April 2008 election held to elect district representatives and to replace those who boycotted Parliament in the aftermath of the 2005 post-election crisis was uncontested as the major opposition parties refused to take part. Rule of law is also recognized in the preamble (paragraph $\mathrm{I}$ ) although, being primarily the function of independent judiciary, its existence (or not) is to be established only empirically in the light of the judicial practice. The system of government being a parliamentary one where fusion of powers is predominant, there hardly is separation of powers that resembles the kind in presidential systems. Given the fact that the ultimate interpreter of the constitution is a non-judicial body, i.e., the House of Federation, Ethiopia has a unique "form" of constitutional review that can hardly be named "judicial review". In practice, the task of review is undertaken by the House of Federation. Owing to the fact that very few cases 
have been disposed of by the HOF thus far (see Kassa 2007), whether the review system is robust enough to restrict the power of government and protect the (individual) rights of citizens is rather dubious. This and other imperfections in the area of human rights protection seem to suggest that constitutionalism is weak in Ethiopia - note for example the fact that the special human rights institutions (i.e., the Human Rights Commission and the Institution of the Ombudsperson) were legally established in 2000 but only became operational in 2005. To date, they have not fully ensconced themselves in the system so as to be able to promote, monitor, and protect human rights. Note further the recent reports on Ethiopia's human rights performance such as that of the Human Rights Watch (2008).

It is important to note that when constitutionalism is weak, so is efficacy of the constitution. When such is the case, a stronger call for constitutional fidelity is warranted. Now we turn to the discussion of the notion of fidelity with a view to exploring its potential for a redemptive constitutional practice which, if successfully done, can not only strengthen constitutionalism but also generates a derivative legitimacy. Constitutionalism so strengthened and legitimacy so generated, it is hoped, can in turn help close the gap between constitutional design and constitutional practice.

\section{Constitutional Fidelity: Basic Law, Higher Law, and Our Law}

Jack Balkin (2007) says that three things are pivotal for the effective implementation of a constitution, namely that the constitution is (or is perceived to be) a basic law, a higher law, and "our" law. Jack Balkin (2007) says that when the constitution becomes 'our' law, it (re) constitutes the polity by linking the generations past to the generations to come in the interpretive process of the present. Writing about the US constitution from a decidedly American perspective, he says:

A successful constitution [...] must simultaneously serve three functions: It must be basic law [,] a framework for governance that allocates powers and responsibilities. It must be higher law [,] a source of aspiration and a reflection of values that stand above ordinary law and hold it to account. And it must be our law, an object of attachment that we see as the product of our collective efforts as a people. Viewing the Constitution as our law involves a collective identification with those who came before us and those who will come after us. The Constitution as our law constitutes us as a people that extends over time. This collective identification is a constitutional story that allows us to regard the Constitution as our own even if we never officially consented to it. (Balkin 2007).

These three elements are necessary as an expression of fidelity. Constitutional fidelity is necessary for the effective implementation of a constitution. Constitutional fidelity, conformity of our actions, decisions, and practices to the letter and spirit of the constitution, is a means to an end, the end being the achievement of constitutional legitimacy (Michaelman 2007: I-2). Frank Michaelman, also writing from an American perspective, says that there are four models of fidelity to choose from namely, the rightness model, the 
posterity model, the wisdom model, and the we-the-people model (Michaelman 2007: 3). The rightness model suggests that the constitution is legitimation-worthy because its contents have moral rightness, the goodness of the ideas in the constitution, as a consequence of which it calls us to loyalty to the text of the constitution. It is interesting to note that in Michaelman's scheme, legitimacy is "justified enforceability", and thus to call a law legitimate is to "announce a judgement that you and I are justified in demanding everyone's compliance with that law without having to prove, or even claim to believe in, the genuine first order merits of that law as right, fair, good, just, efficient, prudent, and so on." (Michaelman 2007: 2). The posterity model offers that the constitution is legitimation-worthy because of the need to defer to the framers as a new generation of citizens who identify with our forbears. This causes one to resort to the constitution's authorship to invoke legitimacy. The wisdom model insists on the assumption that the framers "were men of superior political wisdom, dedication, and public spirit." (Michaelman 2007: 4). Hence, the urge to exert fidelity to their understanding or intentions regarding the meaning of the text of the constitution. The we-the-people model suggests that fidelity to the constitution means fidelity to "the political fellowship of the ... people understood as a communion-in-self-government that spans the generations." (Michaelman 2007: 5).

In a similar vein, Erwin Chemerinsky (2007: 4) maintains that fidelity needs to be directed to the text, the goals of the constitutional provision, the precedents and historical practices that unfolded after the adoption of the constitution, and the contemporary needs of the society in which the constitution is being applied. Robin West (2007: I) wants us to look to the political or legislated constitution (in the American context, to the reconstruction era amendments, for example) to stress what we ought to demonstrate fidelity to them. Apparently, it is this preference for the political (or the popular) constitution that makes her call for a more constitutionally attentive legislature and a more constitutionally responsible voting public. Common in all the above mentioned models and "objects" of fidelity is the need for conformity in terms of our interpretation and practice to the constitution by a constant going back, a recourse, to the text, its authorship, and the wisdom generated by the authors and subsequent precedents and practices, the union created by the constitution, and the ever changing needs of a changing society.

Through such retracing, through such fidelity, decisions (both the creative and interpretive ones) - that is, the legislative and judicial ones - can contribute to the 'production' of derivative legitimacy. This in turn fosters the efficacy of the constitution. Efficacy reinforces the strength and independence of constitutional institutions. In time, this 'emancipates' the constitutional legal institutions from subservience to the politics. This process further entrenches constitutionalism. The end result, as Mattei (1997: 12) suggests, will be that "the armed men" will at last "obey the unarmed ones." In his paper, he asks rather cynically, "why should the armed man obey the [courts]?" given the fact that the courts command neither the purse nor the sword. In Ethiopia, the fact that the ultimate constitutional arbiter is the HoF, a political body, does not readily warrant such a prompt independence of constitutional law from politics. On the other hand, because the HoF enjoys a greater degree of trust from the political offices (at least in the era of 
EPRDF dominance), it provides a wider opportunity for doing more aggressive work of redemptive constitutional interpretation. Redemptive constitutional practice can thus have a ready-made institutional articulation through the HoF cum the CCI.

What does fidelity require? In simple terms, as has been hinted at repeatedly, it requires faithfulness to the constitutional text, or to the intention of the framers, or to the values and principles underpinning the constitution, etc. Prior to fidelity, there must be a faith in the legitimacy of constitutions. That, apparently, requires a leap on the part of the faithful. So even when there is no reasoned evidence as to the existence of original legitimacy, legitimacy is, in a manner of speaking, willed into existence and adherents remain true to it - or so I understand Jack Balkin (2007) as saying. He, rightly, restricts faithfulness to the text and its values and principles, not to the framers' expectations. See also Balkin (2008) for an elaborate discussion of why the framers' original intent or expectation should be discarded. In the Ethiopian context, this faithfulness needs to be practiced at various levels, namely at the legislative level (where supposedly political fiat, or will, predominates), at the adjudicative level (where supposedly reason predominates), and at the electoral level (where voters' interest and passion predominates). A constitutionally attentive legislator, a constitutionally informed interpreter, and a constitutionally responsible voting public are a sine qua non to constitutional fidelity (West 2007: I). The question arises, however: how can we be expected to be faithful to a constitution that lacks original legitimacy? The question, reframed, is: how can fidelity exist when legitimacy is dubious? Balkin's call for redemption through recourse to the principles of the constitution that connects the present generation to the past and future generations (Balkin 2007), and West's call for a more political, or amendment-oriented, or "legislated" constitution for a new constitutional vision (West 2007), are instructive here. In fact, the question suggests that legitimacy is necessary for fidelity. But fidelity must be looked at as a means, and legitimacy must be looked at as an end. Fidelity has the potential not only of generating a (derivative) legitimacy but also of redeeming the deficit of (original) legitimacy that was caused by a flaw in the process of the making of the constitution. The answer to the question, then, is: through (more) faithfulness. Exerting more faithfulness is easily done when the generation of the framers is still active in the public life of Ethiopia. The government of EPRDF (which is still in power), being the predominant force behind the making of the constitution, has the responsibility of applying the utmost fidelity to the constitution - through aggressive acts of implementation - so that, through such acts it can help the constitution garner an earned legitimacy thereby redeeming the fractured original legitimacy. In practice, this means, among other things, for the EPRDF to concede temporary losses for the sake of a better stability of the constitution, the strength and durability of which, incidentally, is the greater victory for this generation of EPRDF members who helped frame the constitution. More fidelity bolsters a redemptive constitutional practice. Such practice helps bridge the gap between constitutional design and constitutional practice. 


\section{Conclusions}

By way of conclusion, let me attempt to answer the questions I raised at the beginning of this article. That constitution making is more than a mechanical act of producing a written text is noted. That it involves a careful choice of constitutional models befitting the core character of the polity is also underscored. In polities founded by design (be it those emerging out of a conflicted past or otherwise), the notion of popular consent is important. In post-conflict societies, the constitution serves as a peace document that makes, keeps, and builds peace thereby transforming conflict into a positive re-constitutive force. In such societies, the design of the constitution is as important as, if not more important than, its practice. All the relevant political actors, all the sectors of the concerned public, and all the stakeholders must come to the 'table of covenant' as they seek to make their constitution. They must also be able to participate in the process and to express their consent freely so that they develop a sense of trust and confidence not only in the process but also in the outcome. Exercise of choice is needed for constitutional design.

The design of a constitutional text involves the practical stages of drafting, deliberation, adoption, and ratification. At all these stages, inclusiveness, participation, and a 'bi-directional traffic', in short, consent, are needed. Who is involved at the drafting, deliberation, adoption and ratification stage (and who is excluded at one or more of these stages) determines (the perception of) whose constitution it is, and to that extent, determines its legitimacy. Legitimacy, having a moral, legal, and sociological founding, can come about from the acceptability that the constitution obtains from the vast majority of the people. This is because, of course, in principle, ultimately legitimacy emanates from the sovereignty of the people. For legitimacy, the process must be (democratically) acceptable, the content must be able to capture the principles, ideals, aspirations, and goals of the majority of the people, and the context in which it applies must be optimally compatible to the values in the content.

The implementation of a constitution depends to a large degree on legitimacy, entrenchment of constitutionalism, and efficacy of the constitutional system. Legitimacy determines the authority of the constitution. This in turn impinges on constitutionalism, the principle of limited government, whose activities are guided and constrained by the constitution. Efficacy, which is rooted in compliance (of officials) and obeisance (by the people), comes depending on, inter alia, the strength, autonomy, and neutrality of constitutional institutions. The interplay of the three creates a congenial environment for a better constitutional practice.

In Ethiopia's history, constitutional legitimation of power was rare. Historically, legitimacy is endowed on a regime by force, religion, and tradition. The polity was a product of an amalgam of force and evolution. The first two written constitutions of the 2oth century (of I93I and 1955) were more like a grant from the rulers to the ('beloved') people. Their authority was more symbolic (of modernization) and merely asserted, not exerted. The third (1987) was more like a revolutionary manifesto. It was also a grant with an asserted supremacy and authority. The I99I Transitional Charter and the FDRE 
constitution sought a rapturous break from this tradition. They sought 'to restructure the state and democratize the government'. Having this as a historical background, the FDRE constitution was made in the time between 1992 and 1995 .

The process of the making of the FDRE constitution had its roots in the Transitional Period. The Charter set the tone. The Transitional Government oversaw the process. A Constitutional Commission statutorily established by the Transitional Government prepared the draft and submitted it to the legislature of the time (known then as the Council of Representatives). The draft was discussed in detail in the legislature for about a month (from I2 April-Io May 1994) and was adopted before it was presented for popular discussions. The discussion often looked more like 'educating' or explaining. Subsequent to the discussion and formation of a constitutional assembly in 1994, it was further discussed in the Assembly before it was finally adopted in December 1994 to come into force in August 1995.

Because the drafting, discussion, and adoption was overseen by the Transitional government which was dominated by the EPRDF, to that extent, the original legitimacy of the FDRE is undermined. Among comparative legal scholars, the content of the constitution being predominantly a result of indiscriminate transplantation, has no local legitimacy, i.e., does not resonate well with autochthonous traditions in Ethiopia. The constitutional system being part of the legal tradition that is termed as 'rule of political law', where law is subordinate to politics, the constitution commands minimal authority and efficacy among the Ethiopian public. (Or, so they argue.) One also notes that while conceding that original legitimacy is weak, the system needs to ensure that, through aggressive implementation, the constitution earns its own (derivative) legitimacy. For this, fidelity to the constitution is needed. Constitutional fidelity must be seen as means to bringing about constitutional legitimacy. This in turn leads to an exercise in what scholars call 'redemptive constitutional practice'. The interpretive institutions play a pivotal role in calling us all to fidelity so that the constitution, in the words of Jack Balkin, is not only a 'basic' law, or a 'higher' law, but 'our' law, thereby reconstituting the Ethiopian polity. But the point needs to be stressed: between constitutional design and constitutional practice stands a gap that needs to be filled. That gap can be filled only through legitimacy, constitutionalism, and efficacy. For this, redemptive constitutional practice, conducted through the instrumentality of constitutional fidelity, can be helpful.

\section{References}

Abbink, Jon (1997). Ethnicity and Constitutionalism in Ethiopia. Journal of African Law, 4I: 666.

Ackerman, Bruce (1992). The Future of Liberal Revolution. New Haven, Yale University Press.

Almond, Gabriel and Verba, Sydney ( 1963$)$. The Civic Culture. Princeton, Princeton University Press.

An-Naim, Abdullah Ahmed (ed.) (2003). Human Rights Under African Constitutions: Realizing the Promise for Ourselves. Philadelphia, University of Pennsylvania Press.

Ashenafi, Meaza (2003). Ethiopia: Processes of Democratization and Development. In: Human Rights Under African Constitutions: Realizing the Promise for Ourselves, A. An-Naim (ed.), . Philadelphia, University of Pennsylvania Press, pp.32. 
Balkin, Jack (2007). Original Meaning and Constitutional Redemption (Yale Law School, Public Law Working, Paper No. 140), Constitutional Commentary, 24: 1 .

Balkin, Jack (August 2008). Abortion and Original Meaning (Yale Law School Public Law and Legal Theory, Working Paper No. 128), Constitutional Commentary, 24(IOI): 5, 70.

Bilgin, M. (2007). Democratic Legitimacy and Constitutions (paper presented at the annual meeting of the Law and Society Association, TBA, Berlin, Germany, July 2007). Unpublished manuscript.

Bo Li (2008). What is Constitutionalism?. Perspectives, 6: 2.

Brown, Bernard E. \& Macridis, Roy C. (1996). Comparative Politics: Notes and Readings. Belmont, Wadsworth Publishing Company.

Calvert, H. (1985). British Constitutional Law. London, Blackstone Press.

Chemerinsky, Erwin (2007). Constitutional Interpretation for the Twenty-first Century. Paper presented at the Conference of the American Constitution Society for Law and Policy, July 2007.

Curtis, Michael (1985). Introduction. In: Introduction to Comparative Government, M. Curtis et al. (ed.), New York, Harper \& Row.

Degefa, Aberra (2008a). The Scope of Rights of National Minorities under the Constitution of the Federal Democratic Republic of Ethiopia. Addis Ababa, Faculty of Law (Constitutional Law Series), Addis Ababa University Press.

- (2008b). Equal Recognition of All Ethiopian Languages: Some Observations Concerning the Broadcast Media. Jimma University Law Journal, I (2): pp. 223-245.

Elazar, Daniel (1985). Constitution-making: the Pre-eminently Political Act. In: The Politics of Constitutional Change in Industrial Nations: Redesigning the State, Keith G. Banting \& Richard Simeon (eds.), London: Macmillan, pp. 232-248.

- (1994). Federalism and the Way to Peace. Queens: Center for Inter-governmental Relations.

- (2006). Exploring Federalism. Tuscaloosa: University of Alabama Press.

- (2008). Constitution-making: The Pre-eminently Political Act. http://www.jcpa.org/dje/articles $3 /$ constisramer.htm.

Fallon, Richard H. Jr. (2005). Legitimacy and the Constitution. Harvard Law Review, I18 (6): pp. 1789-1853. Federal Negarit Gazeta (1995). Year 1, No.I.

Fleming, James (2006). The New Constitutional Order and the Heartening of Conservative Aspirations. Fordham L. Review, 75(537).

Hamilton, A. et al. (1999). The Federalist Papers (No.I). New York: Mentor.

Haile, Minassie (2005). Comparing Human Rights in Two Ethiopian Constitutions: The Emperor's and the "Republic's"-Cucullus non Facit Monachum". Cardozo J. Int'l \& Comp. L, I3 (I).

Henkin, Louis (2002). Elements of Constitutionalism. Unpublished manuscript.

Human Rights Watch (2008). Collective Punishment: War Crimes and Crimes against Humanity in the Ogaden area of Ethiopia's Somali Regional State.

- (2008). Why am I Still Here? The 2007 Horn of Africa Renditions and the Fate of those Still Missing.

International Crisis Group (ICG) (2009). Ethiopia: Ethnic Federalism and its Discontents. Africa Report No. 3, 4, September 2009. www.reliefweb.int/rw/rwb.nsf.

Jain, M.P. (1994). Indian Constitutional Law (4th ed). Agra/Nagpur: Wadhwa and Company.

James, Wendy et al. (1986). The Southern Marches of Imperial Ethiopia. Essays in History and Social Anthropology. Cambridge: Cambridge University Press.

- (2002). Remapping Ethiopia: Socialism and After. Oxford/Athens, OH/Addis Ababa: James Currey/ Ohio Univ Press/ AAU Press.

Johnston, Alexander et al. (eds.) (1993). Constitution-Making in the New South Africa. London and New York: Leicester University Press. 
Kassa, Getahun (2007). Mechanisms of Constitutional Control: A Preliminary Observation of the Ethiopian System. Afrika Focus, 20 (I-2): pp. 88-93.

Khan, Rais A. \& James D. McNiven (I990). An Introduction to Political Science. Scarborough, Ontario: Nelson Cananda.

Kommers, Donald (1985). The Government of West Germany. In: Introduction to Comparative Government. M. Curtis et al. (eds.), New York: Harper \& Row Publishers, pp. 197.

Koskenniemi, Martti (2006). From Apology to Utopia: The Structure of International Legal Argument. Cambridge: Cambridge University Press.

Legesse, Asmarom (2006). Oromo Democracy: An Indigenous African Political System Trenton, NJ/Asmara: The Red Sea Press.

Legrand, Pierre (1997). The Impossibility of "Legal Transplants". Maastricht Journal of European and Comparative Law 4: III et seq.

Lyons, Terrence (1996). Closing the Transition: The May 1995 Elections in Ethiopia. Journal of Modern African Studies, 34 (I): I2I-142.

Markakis, John (2007). Federalism and Constitutionalism in the Horn of Africa. In: Constitutionalism and $\mathrm{Hu}-$ man Security in the Horn of Africa (Proceedings of a Conference). Addis Ababa: Inter-Africa Group, pp. 49.

Mattei, Ugo (1995a). The New Ethiopian Constitution: First Thoughts on Ethnical Federalism and the Reception of Western Institutions. Cardozo Electronic Law Bulletin. http://www.jus.unitn.it/cardozo/Review/constitutional/Mattei2.html.

- (1995b). The New Ethiopian Constitution: First Thoughts on Ethnical Federalism and the Reception of Western Institutions. In: Transplants, Innovation, and Legal Tradition in the Horn of Africa, Elisabetta Grande (ed.), Torino: L'Harmattan, pp. III-I29.

- (1997). Three Patterns of Law: Taxonomy and Change in the World's Legal Systems. Am. J. Comp. Law, 45 (5).

- (1998). Patterns of African Constitution in the Making (unpublished paper presented at the International Conference on African Constitutions at the University of Bologna, 27 July 1998).

- (1999). Patterns of African Constitution in the Making. Cardozo Electronic Law Bulletin. http:www.jus. unitn.it/Cardozo/Review/Constitutional/Mattei.html.

Michaelman, Frank (2007). Fidelity and Legitimacy. (Paper presented at a conference of the American Constitution Society for Law and Policy, July 2007.).

Murphy, Walter (1993). Constitutions, Constitutionalism, and Democracy. In: Constitutionalism and Democracy, Greenberg et al (eds.), Transitions in the Contemporary World, New York: Oxford University Press, pp. 7-I2.

- (1995). American Constitutional Interpretation. Westbury, NY: The Foundation Press.

- (2000). Constitutional Interpretation as Constitutional Creation (paper given at UC, Irvine, November I, 2000). Unpublished manuscript.

Paul, James C.N. (2000). Ethnicity and the New Constitutional Orders of Ethiopia and Eritrea. In: Autonomy and Ethnicity: Negotiating Competing Claims in Multi-ethnic States, Yash Ghai (ed.), Cambridge: Cambridge University Press, pp.189.

Regassa, Tsegaye (2001). Ethnic Federalism and the Right to Self-determination as a Constitutional Legal Solution to the problem of Multi-ethnic Societies: The Case of Ethiopia. Unpublished LL.M Thesis: Faculty of Law, University of Amsterdam.

- (2007a). Beyond and Above the Heat of Politics. The Office of the President of the Republic in the Ethiopian Constitutional System. Unpublished manuscript.

- (2007b). Learning to See through Others' Lens. Issues of Self-determination in Ethiopia. Unpublished manuscript.

Rehinstein, Max (1954). Max Weber on Law in Economy and Society. Cambridge: Harvard University Press.

Rorty, Richard (1996). Who are We?: Moral Universalism and Economic Triage. Diogenes, 44 (I): pp. 5-15. 
Sajo, Andras (1999). Limiting Government: An Introduction to Constitutionalism. Budapest and New York: Central European University Press.

Schlee, Gunther (2003). Redrawing the Map of the Horn: The Politics of Difference. Africa 73 (3): pp. 343-368. Shively, W. Phillips (1999). Power and Choice: An Introduction to Political Science. Boston: McGraw Hill.

Sunstein, Cass R. (2002). Designing Democracy: What Constitutions Do. New York and Oxford: Oxford University Press.

The Constitution of the Peoples' Democratic Republic of Ethiopia. Negarit Gazeta, I (1987) (September 1987).

Tushnet, Mark (1999). The New Constitutional Order and the Chastening of Constitutional Ambition. Harv. L.Rev, II3 (29).

Watson, Alan (1993). Legal Transplants: an Approach to Comparative Law. Athens: The University of Georgia Press.

Weiller, Joseph (1999). The Constitution of Europe: "Do the New Clothes Have an Emperor?" and other Essays. Cambridge: Cambridge University Press.

West, Robin (2007). Constitutional Fidelity and Democratic Legitimacy (paper presented at a conference of the American Constitution Society for Law and Policy, July 2007).

Wiarda, Howard J. (1993). Introduction to Comparative Politics: Concepts and Processes. Belmont: Wadsworth Publishing Company.

Zoethout, C.M. et al. (eds.) (1996). Constitutions in Africa: The Quest for Autochthonous Principles. Deventer: Gouda Quint. 